Photovoltaic

https://doi.org/10.52825/thwildauensp.v1i.31

(C) Authors. This work is licensed under a Creative Commons Attribution 4.0 International License

Published: 15 June 2021

\title{
Advances in Conversion Efficiency and Thermal Stability of the Perovskite-based Solar Cell: Review
}

\author{
N'Detigma Kata ${ }^{1,2}$ [https://orcid.org/0000-0001-8757-9825], Hodo-Abalo SAMAH ${ }^{2}$, Kodjo Kpode ${ }^{2}$ and \\ Amadou Seidou Maiga ${ }^{1}$ \\ ${ }^{1}$ Laboratoire Electronique, Informatique, Télécommunication et Energies Renouvelables, \\ Saint-Louis, Senegal, \\ ${ }^{2}$ Faculté des Sciences et Techniques, Université de Kara, Togo.
}

\begin{abstract}
This paper presents a small review on the technological advances made on the perovskite-based solar cell. Through this summary of the results of the research on perovskite, the reader will have an overview of the perovskite material, the different structures of a perovskite solar cell, and the opto-electrical properties of such cell as well as the electrical models used in its simulation. Finally, the paper presents in a very brief way the challenges that this technology will have to overcome before finding its place in the photovoltaic market.
\end{abstract}

Keywords: perovskite solar cell, review, thermal stability.

\section{Introduction}

Among the photovoltaic cell technologies, perovskite solar cell technology has become probably the hottest topic in photovoltaics as can be seen in the number of publications and conference topics on the subject. In 2009, Miyasaka et al. developed a perovskite-based cell with an efficiency of $2.2 \%$. But, by replacing Boron with lodine, the efficiency improved to $3.8 \%$. Ten years later, the confirmed efficiency of the single junction cell of a perovskitebased cell was $21 \%$. In 2020 , a perovskite-based solar cell with a conversion efficiency of $25.5 \%$ was achieved by Jeong $M$. and all. Several models of perovskite -based solar cell structure, elaboration and optimization method and simulation models have been proposed in the published studies. In spite of the visible advances in terms of structure stability and conversion performance, much research effort remains to be done to ensure the thermal stability of this cell which will guarantee its commercial success. The objective of this paper is to highlight these advances and to review the manufacturing and simulation models of the perovskite cell in order to bring together the similarities in the methods and structure that will ensure its thermal stability.

\section{Structure of the perovskite solar cell}

Perovskite mineral is used as a photovoltaic solar cell absorber. It can be elaborated from a variety of materials and different synthesis methods. Perovskite was discovered in 1839 in the Ural Mountains in Russia and named after the Russian mineralogist L.A.Perovskite [1]. The chemical formula of this mineral is $\mathrm{CaTiO} 3$ (calcium titanium oxide). Compounds that have a similar structure to $\mathrm{CaTiO} 3(\mathrm{ABX} 3)$ are called perovskites. In general, in the $\mathrm{ABX} 3$ structure of perovskite, $A$ is a large monovalent cation that occupies the cubooxctahedral sites in a cubic space. $B$ is a small divalent metal cation that occupies the octahedral sites and $\mathrm{X}$ is an anion (typically a halogen, however, $\mathrm{X}$ can be oxygen, carbon or nitrogen). The 
structure of perovskite and its stability is quantified by two crucial parameters: the tolerance factor $(t)$ given by equation 1 and the octahedral factor $(\mu)$.

$$
t=\frac{\left(R_{A}+R_{X}\right)}{\sqrt{2\left(R_{B}+R_{X}\right)}}
$$

This factor is a ratio of the ionic radius of the divalent cations $R_{A}, R_{B}$ and the radius of the anion $R_{X}$. These two parameters are generally between 0.81 and 1.11 for $t$ and then 0,44 and 0.90 for $\mu \mu$ [1]. The perovskite-based solar cell has a variety of architecture. As in other photovoltaic cell technologies, the perovskite cell has an electron transport layer (ETL) and a hole transport layer ( $\mathrm{HTL}$ ) in addition to the perovskite absorber layer. Thus, the configuration of the cell is very crucial to expect a high-performance perovskite cell. From the literature, two configurations stand out for perovskite based cells: the planar configuration and the mesoporous configuration. Each configuration can be elaborated according to the conventional structure $(\mathrm{N}-\mathrm{i}-\mathrm{P})$ or the inverse structure $(\mathrm{P}-\mathrm{i}-\mathrm{N})$. The following figures illustrates its two configurations.

a)

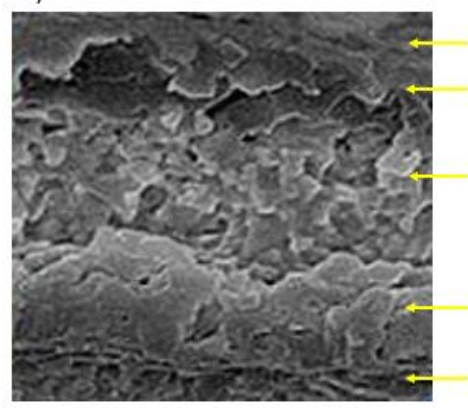

b)

Electrode
HTM
Pérovskite
ELT
FTO

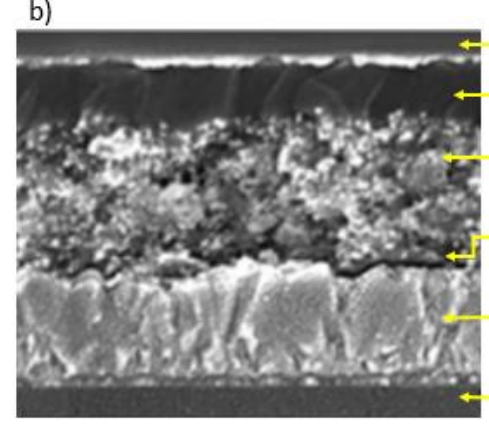

\section{Electrode}

HTM

\section{Pérovskite}

Mesoporous scaffold

\section{ELT \\ FTO}

Figure 1. The perovskite-based solar cell configuration: a) the planar configuration and b) the mesoporous configuration.

The evolution of this technology is meteoric with a yield that has evolved from $3.3 \%$ in 2009 to $25 \%$ in 2020 (figure 2).

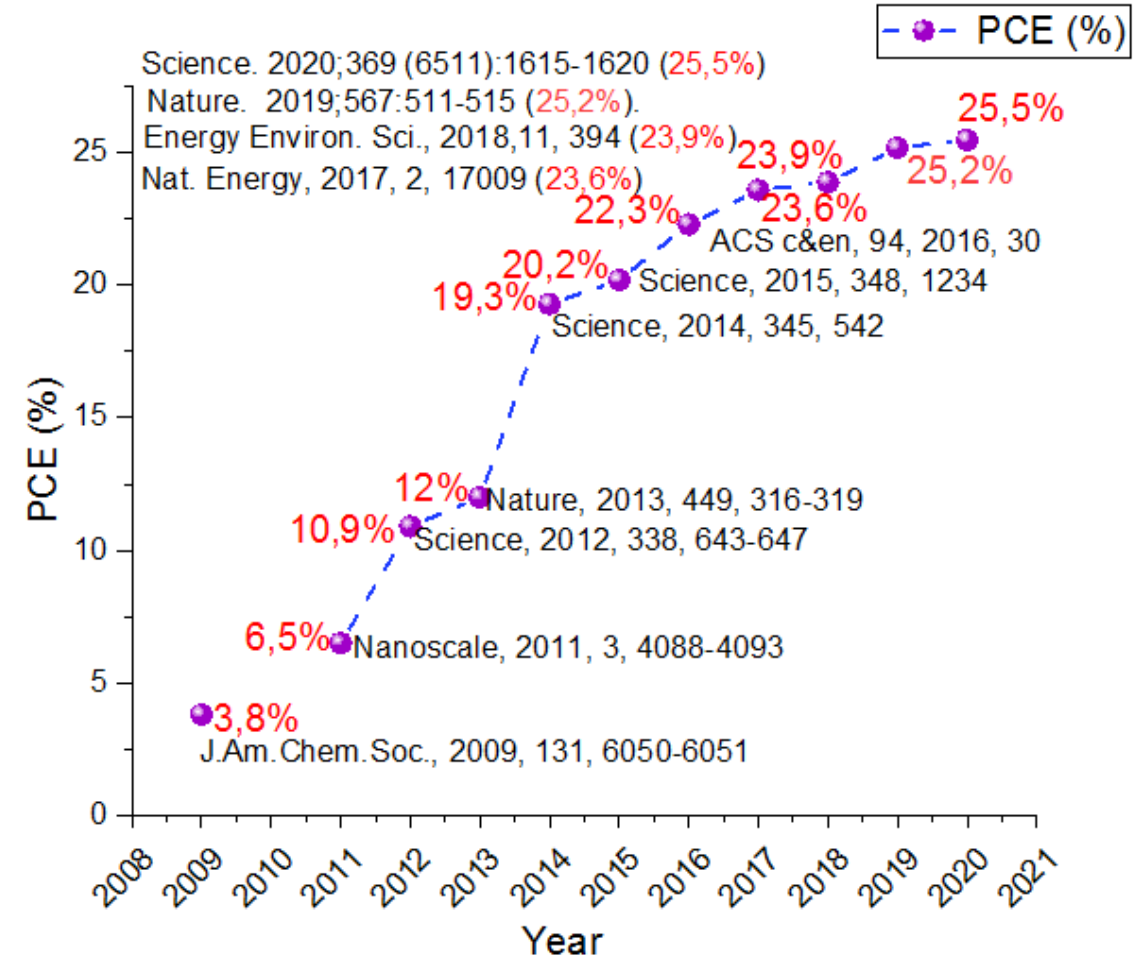

Figure 2. The best annual yield of solar cells based on perovskite. 
This performance is partly due to the understanding in the structure of the layers of this cell, the treatment reserved to their interface and the interest that this technology arouses in research. The following table summarizes the different structures of the perovskite-based cell studied in the literature. It is necessary to recall that the choice of a structure aims at the improvement and the stability of the existing cell.

Table 1. The different structures of the perovskite-based cell studied in the literature.

\begin{tabular}{|c|c|c|c|}
\hline Structures & PCE & $\begin{array}{l}\text { Stability } \\
\text { time }\end{array}$ & Ref \\
\hline FTO / $\mathrm{TiO}_{2}-\mathrm{Cl} / \mathrm{MAPbl}_{3} /$ Spiro-OMeTAD / Au & $21 \%$ & $2000 \mathrm{~h}$ & [3] \\
\hline FTO / Doped $\mathrm{C}_{60} /$ mixed perovskite / Spiro-OMeTAD / Au & $17 \%$ & $650 \mathrm{~h}$ & [4] \\
\hline Glass / ITO / PEDOT:PSS / $\mathrm{MAPbl}_{3} /$ PCBM / EFGnPs-F / Al & $14.3 \%$ & 30 days & [5] \\
\hline $\mathrm{FTO} / \mathrm{LBSO} / \mathrm{MAPbl}_{3} / \mathrm{PTAA} / \mathrm{Au}$ & $21.2 \%$ & $120 \mathrm{~h}$ & [6] \\
\hline $\mathrm{FTO} / \mathrm{TiO}_{2} / \mathrm{MAPbl}_{3} / \mathrm{PTAA} / \mathrm{Au}$ & $19.6 \%$ & $120 \mathrm{~h}$ & \\
\hline $\mathrm{FTO} / \mathrm{LBSO} / \mathrm{MAPbl}_{3} / \mathrm{NiO} / \mathrm{Au}$ & - & $100 \mathrm{~h}$ & \\
\hline $\begin{array}{l}\text { GlassFTO / c-TiO } / 2 \text { mp- } \mathrm{TiO}_{2} / \text { mixed perovskite / Spiro- } \\
\text { OMeTAD-SWCNT }\end{array}$ & $15 \%$ & $580 \mathrm{~h}$ & \\
\hline FTO / c- $\mathrm{TiO}_{2} / \mathrm{m}-\mathrm{TiO}_{2} /$ perovskite / Spiro-OMeTAD / Au & $14.6 \%$ & $300 \mathrm{~h}$ & [7] \\
\hline FTO / c- $\mathrm{TiO}_{2} / \mathrm{m}-\mathrm{TiO}_{2} /$ perovskite $/ \mathrm{ZrO}_{2} /$ Carbon & $11.9 \%$ & $12000 \mathrm{~h}$ & [8] \\
\hline $\mathrm{FTO} / \mathrm{c}-\mathrm{TiO}_{2} / \mathrm{m}-\mathrm{TiO}_{2} / \mathrm{Cs}_{5} \mathrm{M} / \mathrm{HTL} / \mathrm{Au}$ & $21.2 \%$ & $250 \mathrm{~h}$ & [8] \\
\hline $\mathrm{FTO} / \mathrm{c}-\mathrm{TiO}_{2} / \mathrm{m}-\mathrm{TiO}_{2} / \mathrm{Cs}_{0} \mathrm{M} / \mathrm{HTL} / \mathrm{Au}$ & - & $250 \mathrm{~h}$ & \\
\hline $\mathrm{ITO} / \mathrm{cp}-\mathrm{TiO}_{2} / \mathrm{ms}-\mathrm{TiO}_{2} /$ perovskite / PTAA / Au & $20.6 \%$ & $160 \mathrm{~h}$ & [9] \\
\hline $\begin{array}{l}\mathrm{ITO} / \mathrm{cp}-\mathrm{TiO}_{2} / \mathrm{ms}-\mathrm{TiO}_{2} / \text { perovskite / Spiro-mF / } \mathrm{Au} \\
\mathrm{ITO} / \mathrm{cp}-\mathrm{TiO}_{2} / \mathrm{ms}-\mathrm{TiO}_{2} / \text { perovskite / Spiro-oF/ Au }\end{array}$ & $24.8 \%$ & $500 \mathrm{~h}$ & [10] \\
\hline FTO $/ \mathrm{bl}-\mathrm{TiO}_{2} / \mathrm{mp}-\mathrm{TiO}_{2} / \mathrm{MAPb}\left(\mathrm{I}_{1-\mathrm{x}} \mathrm{Br}_{\mathrm{x}}\right) / \mathrm{PTAA} / \mathrm{Au}$ & $16.2 \%$ & - & [11] \\
\hline FTO / PEDOT:PSS / MAPb $\left(I_{3-x} \mathrm{Cl}_{\mathrm{x}}\right)$ / PCBM / Al & $17.7 \%$ & - & [12] \\
\hline ITO / PEIE / $\mathrm{TiO}_{2}$ / perovskite / Spiro-OMeTAD / Au & $19.3 \%$ & - & [13] \\
\hline $\mathrm{FTO} / \mathrm{bl}-\mathrm{TiO}_{2} / \mathrm{mp}-\mathrm{TiO}_{2} / \mathrm{FAPbl}_{3} / \mathrm{PTAA} / \mathrm{Au}$ & $20.2 \%$ & - & [14] \\
\hline
\end{tabular}

If these different structures of the perovskite cell are inexpensive to develop, it should be noted that the structural, electrical and optical properties of the perovskite cell degrade when exposed to the ambient air. This degradation, which is one of the major challenges to overcome if the technology is to appear on the photovoltaic market, is simply due to the reaction of the perovskite layer with the oxygen in the air and with water vapor.

\section{Electrical and optical properties of the perovskite solar cell}

The optical band gap of the halide-based perovskite materials used is about $1.6 \mathrm{eV}$. The absorption of these materials covers only a fraction of the ultraviolet and visible light; $45 \%$ to $50 \%$ of the entire solar spectrum [15] [16].

However, the absorption range of single crystal perovskite is red-shifted [17]. The absorption in single crystal perovskite starts from $850 \mathrm{~nm}$ while it starts at $780 \mathrm{~nm}$ for polycrystalline thin films [18].

This absorption shift in the single crystal is due to the enhanced use of below-bandgap absorption attributed mainly to the indirect-bandgap absorption transition with a bandgap of $60 \mathrm{meV}$ smaller than the direct bandgap. The absorption coefficient of the below bandgap is small compared to that of the above-gap transition making the below bandgap absorption negligible in polycrystalline thin films but abvious in thick single crystals [19].

Z. Cheu showed that the absorption coefficient of single crystal perovskite is an order of magnitude higher than those of conventional ruthenium dyes. Liu et al., have shown that perovskite material is an excellent absorber in the visible spectrum, but very transparent in the near infrared spectrum [19]. 
Blessing E. et al [20], observed similar results to those demonstrated by Aharon et al [21], concerning the improvement of the absorption of the perovskite cell and the decrease of the optical conductivity when the volumetric ration of methylammonium lead bromine introduced in a fixed volume of MAPbI3 increases. The knowledge of the different optical properties and absorption limits and the search for methods to extend the absorption range will contribute to the improvement of the performance of the perovskite technology. This quest for performance improvement also involves simulation studies using electrical models of the solar cell.

\section{Electrical model of the perovskite cell}

The current-voltage characteristic of a cell does not provide reasonable insight into the actual mechanisms of charge transport, recombination and storage. As such, an evaluation of the response of a solar cell to a small perturbation of various real inputs such as voltage or light in the frequency domain of the cell remains an essential method. These mechanisms are summarized in the form of an equivalent circuit that describes the actual physical processes in terms of the passive electrical element and the voltage and current sources. The perovskite cell has been treated theoretically as an ordinary direct band gap semiconductor [22]. Therefore, it is considered as a simple $p$-i-n diode governed by the equivalent circuit equations of the said diode. Many authors have used the one-diode (figure 3a) and twodiode models for the equivalent circuit of the perovskite-based solar cell [23] [24]. In addition to these commonly encountered models, other models often used for organic cells have been used to model perovskite solar cell.

Huang et al. have developed for a perovskite-based solar cell, an equivalent circuit model very close to the one developed by Mazhai for organic cells. The model is shown in Figure $3 b$.

Ebadi et al, proposed an equivalent circuit model for the perovskite cell including electrical components and ionic components [25] (figure 3c).

\section{(a)}

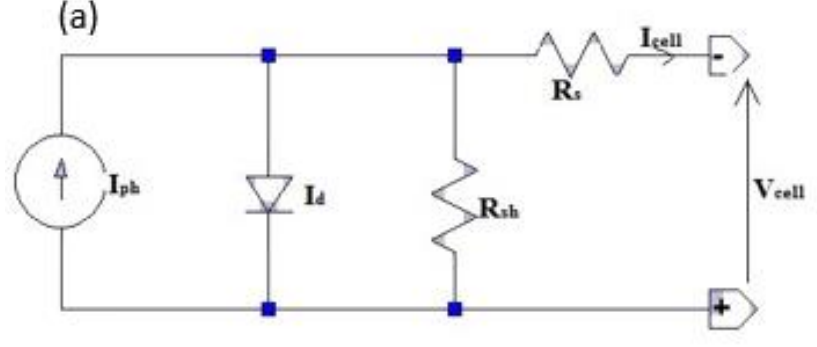

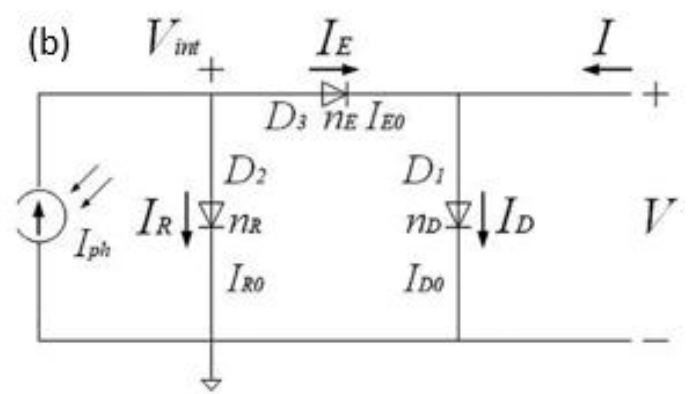

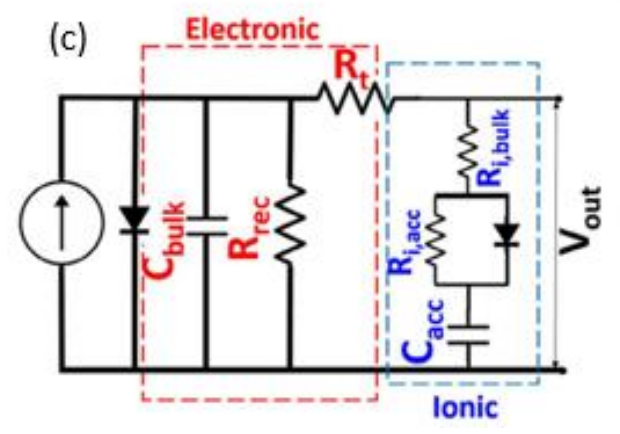

Figure 3. Electrical model of perovskite solar cell: (a) one diode equivalent circuit model, Figure (b) The solar cells' lumped-parameter equivalent circuit model proposed by Mazhari [26] and (c) Equivalent circuit for the fitting photo-voltage rise and decay plots [25] 


\section{Future challenges in perovskite solar cell}

The commercialization of the perovskite-based solar cell remains closely linked to the improvement and stability of its performance. If its efficiency reached $25 \%$ in 2020 , the future challenge of the cell remains its stability.

J. Zhang et al., have shown that the Spiro-OMeTAD hole transport layer used in the elaboration of the perovskite cell contributes to its poor stability when exposed to ambient air [27].

Much effort has been made to develop hole transport layer to replace the Spiro-OMeTAD layer [28] [29] [30]. This layer could be replaced by a Cu:NiOx layer. However, Damian et al., have shown in their study that using $\mathrm{Cu}: \mathrm{NiOx}$ as the hole transport layer results in a huge drop in open circuit voltage and short circuit current. On the other hand, by using $\mathrm{Cu}$ :NiOx/PTAA, the quality of the cell improves as well as its efficiency [31]. In 2020, Mingyu J. et al., replaced the Spiro-OMeTAD hole transport layer with two fluorinated isomers. This process resulted in a perovskite-based cell with $24.8 \%$ efficiency stable at $87 \%$ of its efficiency after 500 hours under humidity conditions without encapsulated [10]. Based on this observation, Yanjie Wu sought to improve the stability of the perovskite-based cell and the mobility of the holes by replacing this layer with a MoO3 layer. In addition, they sought to improve the performance of the cell through the extension of the absorption range to the infrared. For this purpose, a PBDB-TF:BTP-4Cl bulk-heterojunction layer was integrated into the cell [32].

In 2018, Constantina E. et al, developed a perovskite cell with ambition to improve its performance and stability. Thus, by varying the cations $(A=C s, F A, M A)$ and halogen $(X=I$, $\mathrm{Br}, \mathrm{Cl})$ in the perovskite $\mathrm{APbX} 3$, the authors noted not only an improvement in efficiency to $17 \%$, but also a high stability of the cell, low presence of impurity, and low hysteresis when Cesium is used as a cation [33].

The other challenge in perovskite-based cell research is the substitution of $\mathrm{Pb}$ in perovskite with a non-toxic metal. The metals of group 14 of the Mendeleyev table are possible candidates, but their major problem is their chemical instability in the required oxidation state [34]. Considering the enthusiasm that researchers have for this technology, it is certain that in a few years to come, these barriers will be lifted.

\section{Conclusion}

There is no doubt about the performance that perovskite cell can achieve, which rivals crystalline silicon with $25.5 \%$ efficiency in 2020 . The major future challenge facing research on perovskite before its commercialization is the stability of its current structure in outdoor conditions, as it reacts with oxygen in the air and water vapor.

\section{References}

1 Habibi M, Zabihi F, Ahmadian-Yazdi MR, Eslamian M. Progress in emerging solutionprocessed thin film solar cells - Part II: Perovskite solar cells. Renewable and Sustainable Energy Reviews. 2016 09;62:1012-1031. https://doi.org/10.1016/

2 Green MA, Ho-Baillie A, Snaith HJ. The emergence of perovskite solar cells. Nature Photonics. 201406 27;8(7):506-514. https://doi.org/10.1038/nphoton.2014.134.

3 Pitchaiya S, Natarajan M, Santhanam A, Asokan V, Yuvapragasam A, Madurai Ramakrishnan V, Palanisamy SE, Sundaram S, Velauthapillai D. A review on the 
classification of organic/inorganic/carbonaceous hole transporting materials for perovskite solar cell application. Arabian Journal of Chemistry. 2020 01;13(1):2526-2557.

https://doi.org/10.1016/j.arabjc.2018.06.006.

4 Wang Z, McMeekin DP, Sakai N, van Reenen S, Wojciechowski K, Patel JB, Johnston MB, Snaith HJ. Efficient and Air-Stable Mixed-Cation Lead Mixed-Halide Perovskite Solar Cells with n-Doped Organic Electron Extraction Layers. Advanced Materials. 2016 Dec 01;29(5):1604186. https://doi.org/10.1002/adma.201604186.

5 Kim G, Jang H, Yoon YJ, Jeong J, Park SY, Walker B, Jeon I, Jo Y, Yoon H, Kim M, Baek J, Kim DS, Kim JY. Fluorine Functionalized Graphene Nano Platelets for Highly Stable Inverted Perovskite Solar Cells. Nano Letters. 201709 14;17(10):6385-6390. https://doi.org/10.1021/acs.nanolett.7b03225

6 Shin SS, Yeom EJ, Yang WS, Hur S, Kim MG, Im J, Seo J, Noh JH, Seok SI. Colloidally prepared La-doped BaSnO3 electrodes for efficient, photostable perovskite solar cells. Science. 201703 30;356(6334):167-171. https://doi.org/10.1126/science.aam6620

7 K Aitola K, Domanski K, Correa-Baena J, Sveinbjörnsson K, Saliba M, Abate A, Grätzel M, Kauppinen E, Johansson EMJ, Tress W, Hagfeldt A, Boschloo G. High TemperatureStable Perovskite Solar Cell Based on Low-Cost Carbon Nanotube Hole Contact. Advanced Materials. 201702 23;29(17):1606398. https://doi.org/10.1002/adma.201606398

8 Grancini G, Roldán-Carmona C, Zimmermann I, Mosconi E, Lee X, Martineau D, Narbey S, Oswald F, De Angelis F, Graetzel M, Nazeeruddin MK. One-Year stable perovskite solar cells by 2D/3D interface engineering. Nature Communications. 201706 01;8(1). https://doi.org/10.1038/ncomms15684

9 Duong T, Wu Y, Shen H, Peng J, Zhao S, Wu N, Lockrey M, White T, Weber K, Catchpole K. Light and elevated temperature induced degradation (LeTID) in perovskite solar cells and development of stable semi-transparent cells. Solar Energy Materials and Solar Cells. 2018 Dec;188:27-36. https://doi.org/10.1016/j.solmat.2018.08.017

10 Jeong M, Choi IW, Go EM, Cho Y, Kim M, Lee B, Jeong S, Jo Y, Choi HW, Lee J, Bae J, Kwak SK, Kim DS, Yang C. Stable perovskite solar cells with efficiency exceeding $24.8 \%$ and 0.3-V voltage loss. Science. 202009 24;369(6511):1615-1620. https://doi.org/10.1126/science.abb7167

11 Jeon NJ, Noh JH, Kim YC, Yang WS, Ryu S, Seok SI. Solvent engineering for highperformance inorganic-organic hybrid perovskite solar cells. Nature Materials. 201407 06;13(9):897-903. https://doi.org/10.1038/nmat4014

12 Nie W, Tsai H, Asadpour R, Blancon J, Neukirch AJ, Gupta G, Crochet JJ, Chhowalla M, Tretiak S, Alam MA, Wang H, Mohite AD. High-efficiency solution-processed perovskite solar cells with millimeter-scale grains. Science. 201501 29;347(6221):522-525. https://doi.org/10.1126/science.aaa0472

13 Kong L, Ma J, Huang H, Zhang R. Crystallization of magnesium niobate from mechanochemically derived amorphous phase. Journal of Alloys and Compounds. 2002 06;340(1-2):L1-L4. https://doi.org/10.1016/s0925-8388(02)00003-8 
14 Yang WS, Noh JH, Jeon NJ, Kim YC, Ryu S, Seo J, Seok SI. High-performance photovoltaic perovskite layers fabricated through intramolecular exchange. Science. 2015 05 21;348(6240):1234-1237. https://doi.org/10.1126/science.aaa9272

15 Bi W, Wu Y, Chen C, Zhou D, Song Z, Li D, Chen G, Dai Q, Zhu Y, Song H. Dye Sensitization and Local Surface Plasmon Resonance-Enhanced Upconversion Luminescence for Efficient Perovskite Solar Cells. ACS Applied Materials \& Interfaces. 202005 07;12(22):24737-24746. https://doi.org/10.1021/acsami.0c04258

16 Wu Y, Bi W, Shi Z, Zhuang X, Song Z, Liu S, Chen C, Xu L, Dai Q, Song H. Unraveling the Dual-Functional Mechanism of Light Absorption and Hole Transport of Cu2CdxZn1xSnS4 for Achieving Efficient and Stable Perovskite Solar Cells. ACS Applied Materials \& Interfaces. 202003 20;12(15):17509-17518. https://doi.org/10.1021/acsami.0c00607

17 Ezealigo BN, Nwanya AC, Ezugwu S, Offiah S, Obi D, Osuji RU, Bucher R, Maaza M, Ejikeme P, Ezema FI. Method to control the optical properties: Band gap energy of mixed halide Organolead perovskites. Arabian Journal of Chemistry. 2020 01;13(1):988-997. https://doi.org/10.1016/j.arabjc.2017.09.002

18 Liu Y, Zhang Y, Yang Z, Yang D, Ren X, Pang L, Liu SF. Thinness- and Shape-Controlled Growth for Ultrathin Single-Crystalline Perovskite Wafers for Mass Production of Superior Photoelectronic Devices. Advanced Materials. 201608 29;28(41):9204-9209. https://doi.org/10.1002/adma.201601995

19 Liu F, Zhu J, Wei J, Li Y, Lv M, Yang S, Zhang B, Yao J, Dai S. Numerical simulation: Toward the design of high-efficiency planar perovskite solar cells. Applied Physics Letters. 201406 23;104(25):253508. https://doi.org/10.1063/1.4885367

20 Ezealigo BN, Nwanya AC, Ezugwu S, Offiah S, Obi D, Osuji RU, Bucher R, Maaza M, Ejikeme P, Ezema FI. Method to control the optical properties: Band gap energy of mixed halide Organolead perovskites. Arabian Journal of Chemistry. 2020 01;13(1):988-997. https://doi.org/10.1016/j.arabjc.2017.09.002.

21 Aharon S, Cohen BE, Etgar L. Hybrid Lead Halide lodide and Lead Halide Bromide in Efficient Hole Conductor Free Perovskite Solar Cell. The Journal of Physical Chemistry C. 2014 05;118(30):17160-17165. https://doi.org/10.1021/jp5023407

22 Miyano K, Tripathi N, Yanagida M, Shirai Y. Lead Halide Perovskite Photovoltaic as a Model p-i-n Diode. Accounts of Chemical Research. 201601 12;49(2):303-310. https://doi.org/10.1021/acs.accounts.5b00436

23 Cappelletti M, Casas G, Cédola A, Peltzer y Blancá E, Marí Soucase B. Study of the reverse saturation current and series resistance of p-p-n perovskite solar cells using the single and double-diode models. Superlattices and Microstructures. 2018 Nov; 123:338348. https://doi.org/10.1016/j.spmi.2018.09.023

24 Reza MN, Mominuzzaman SM. Extraction of Equivalent Circuit Parameters for CNT incorporated Perovskite Solar Cells Using Newton-Raphson Method. 2018 10th International Conference on Electrical and Computer Engineering (ICECE). 2018 10th International Conference on Electrical and Computer Engineering (ICECE). 2018 Dec. https://doi.org/10.1109/icece.2018.8636738

25 Ebadi F, Aryanpour M, Mohammadpour R, Taghavinia N. Coupled Ionic-Electronic 
Equivalent Circuit to Describe Asymmetric Rise and Decay of Photovoltage Profile in Perovskite Solar Cells. Scientific Reports. 201908 19;9(1).

https://doi.org/10.1038/s41598-019-48505-6

26 Huang G, Yu F, Xu C. An Analytical Solution to Lumped Parameter Equivalent Circuit Model of Organic Solar Cells. Crystals. 201805 18;8(5):224.

https://doi.org/10.3390/cryst8050224

27 Zhang J, Tan HS, Guo X, Facchetti A, Yan H. Material insights and challenges for nonfullerene organic solar cells based on small molecular acceptors. Nature Energy. 201807 02;3(9):720-731. https://doi.org/10.1038/s41560-018-0181-5

28 Jeon NJ, Lee HG, Kim YC, Seo J, Noh JH, Lee J, Seok SI. o-Methoxy Substituents in Spiro-OMeTAD for Efficient Inorganic-Organic Hybrid Perovskite Solar Cells. Journal of the American Chemical Society. 201405 23;136(22):7837-7840.

https://doi.org/10.1021/ja502824c

29 Jeon NJ, Na H, Jung EH, Yang T, Lee YG, Kim G, Shin H, II Seok S, Lee J, Seo J. A fluorene-terminated hole-transporting material for highly efficient and stable perovskite solar cells. Nature Energy. 201807 09;3(8):682-689. https://doi.org/10.1038/s41560-0180200-6

30 Saliba M, Orlandi S, Matsui T, Aghazada S, Cavazzini M, Correa-Baena J, Gao P, Scopelliti R, Mosconi E, Dahmen K, De Angelis F, Abate A, Hagfeldt A, Pozzi G, Graetzel $M$, Nazeeruddin MK. A molecularly engineered hole-transporting material for efficient perovskite solar cells. Nature Energy. 201601 18;1(2).

https://doi.org/10.1038/nenergy.2015.17

31 Głowienka D, Zhang D, Di Giacomo F, Najafi M, Veenstra S, Szmytkowski J, Galagan Y. Role of surface recombination in perovskite solar cells at the interface of HTL/CH3NH3Pbl3. Nano Energy. 2020 01;67:104186. https://doi.org/10.1016/j.nanoen.2019.104186

32 Wu Y, Gao Y, Zhuang X, Shi Z, Bi W, Liu S, Song Z, Chen C, Bai X, Xu L, Dai Q, Song H. Highly efficient near-infrared hybrid perovskite solar cells by integrating with a novel organic bulk-heterojunction. Nano Energy. 2020 Nov;77:105181. https://doi.org/10.1016/j.nanoen.2020.105181

33 Gkini KE, Antoniadou M, Balis N, Kaltzoglou A, Kontos AG, Falaras P. Mixing cations and halide anions in perovskite solar cells. Materials Today: Proceedings. 2019;19:73-78. https://doi.org/10.1016/j.matpr.2019.07.660

34 Vidyasagar CC, Muñoz Flores BM, Jiménez Pérez VM. Recent Advances in Synthesis and Properties of Hybrid Halide Perovskites for Photovoltaics. Nano-Micro Letters. 2018 09 24;10(4). https://doi.org/10.1007/s40820-018-0221-5 